GEOLOGICAL SURVEY CIRCULAR 592

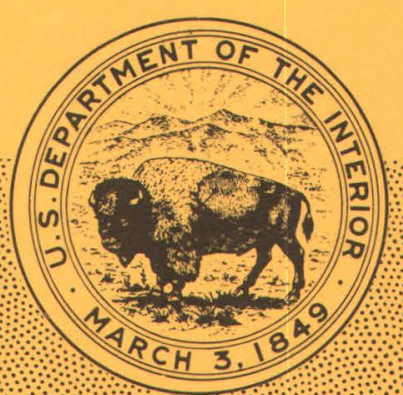

Interpreting Pan-Concentrate

Analyses of Stream Sediments in

Geochemical Exploration for Gold 



\title{
Interpreting Pan-Concentrate
} Analyses of Stream Sediments in Geochemical Exploration for Gold

\author{
By R. P. Fischer and F. S. Fisher
}

GEOLOGICAL SURVEY CIRCULAR 592

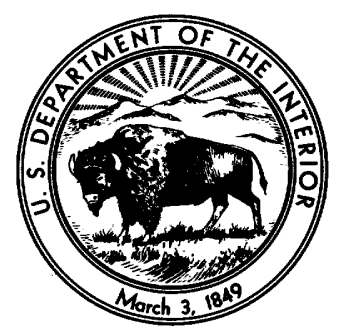




\section{United States Department of the Interior}

WALTER J. HICKEL, Secretary

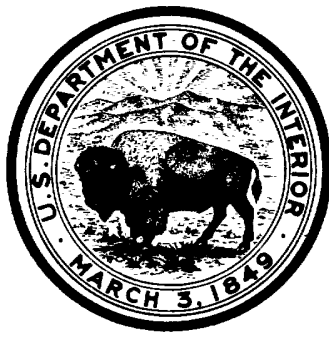

\section{Geological Survey}

William T. Pecora, Director

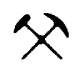

First printing 1968

Second printing 1969

Free on application to the U.S. Geological Survey, Washington, D.C. 20242 


\section{CONTENTS}

Abstract- - - . - . . - . - . Introduction - - - . - . - . - . Sampling and analytical techniques- - - Sample data and analytical results - - - Consistency of analytical results - - -
Sample data and analytical results--Continued Quantitative compatibility of samples with known geologic relations _.

Conclusions - - _

Reference cited _. . . . . . . . . . 2

\section{ILLUSTRATIONS}

Figure 1. Graph of the range, on a logarithmic scale, of analytical determinations for samples listed in tables 2 and 3 that were analyzed as two or three separate splits - . . . . . . . . . . . . . . . . . . . . . . . . . . . .

2. Map showing sample localities and character of mineralized areas in San Juan Mountains, Colo

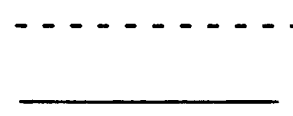

\section{TABLES}

Table 1. Samples from streams draining apparently barren areas _.

2. Samples from streams draining weakly mineralized areas that contain only a few

3. Samples from streams draining well-mineralized areas that contain numerous veins and some very productive mines _............................ 



\title{
Interpreting Pan-Concentrate Analyses of Stream Sediments in Geochemical Exploration for Gold
}

\author{
By R. P. Fischer and F. S. Fisher
}

\begin{abstract}
A study of methods of collecting and processing samples to determine whether or not gold is present in areas of moderate size was undertaken in the northwestern part of the San Juan Mountains, Colo. As part of this study, 57 samples of pan concentrates were taken from streams draining three types of areas: (1) "barren" areas, where gold mineralization might be geologically possible but no deposits are known, (2) slightly mineralized areas that contain only a few known veins and prospects and small mines, and (3) well-mineralized areas that contain numerous veins and some very productive mines. The concentrate samples were analyzed by the fire-assay-atomic-absorption method.
\end{abstract}

Replicate analyses of large samples gave results consistent enough to permit placing considerable confidence in the results obtained for smaller samples on which only one analysis was made. For general field practice, it is necessary to pan only enough sand and gravel to yield about $\mathbf{1 5}$ grams of concentrate.

The analytical results are also quantitatively compatiole with known geologic relations and indicate that a few samples from a stream are adequate to distinguish between "barren" and mineralized areas and to determine the relative amount of gold in mineralized areas. In other areas of similar gold deposits, data of this type should help decide whether more intensive search for gold deposits is justified.

\section{INTRODUCTION}

As part of its Heavy Metals program to appraise and enhance domestic resources of mineral raw materials that are in short supply, the U.S. Geological Survey is studying techniques of geologic sampling and their application to mineral exploration. In 1967 a project was started in the northwestern San Juan Mountains, Colo., to study several methods of collecting and processing samples in order to determine easily and quickly whether or not gold is present in areas of a few square miles. One method tried is described here. It consisted of panning known amounts of sand and gravel from selected streams, weighing the heavymineral concentrates and analyzing them by fire assay and atomic absorption. The panning practice used did not differ from that of the oldtime prospector, but the more sensitive analytical procedure available today offers a distinct advantage. Reasonably reproducible results that seem to be quantitatively meaningful were obtained from 57 samples. This type of sampling should be usable in other areas where similar gold deposits might be present, and the results should help decide whether more intensive search for gold deposits might be justified.
Willard Leedy and Mark Voultsos help ed in the collection and panning of samples in the field. W. D. Goss, L. B. Riley, Claude Huffman, Jr., and J. A. Thomas of the U.S. Geological Survey did the gold analyses.

\section{SAMPLING AND ANALYTICAL TEC -NIQUES}

All samples were sand and gravel from the upper part of the alluvial fill, and at each sample locality this material was taken from one or more places along the stream where placer gold is apt to accumulate, such as the head or foot of stream bars, behind boulders, in moss-covered banks, and in ratural riffles on bedrock. The samples were taken to determine the presence of gold in the stream sediments and its relative amount; they were not adequate to determine or estimate the gold content of the streambed fill.

Samples were panned in the field in 11-and 14-inch gold pans. They were not weighed individually, but it was determined that the small pan contained about 3,500 grams (nearly 8 pounds) of sand and gravol when filled and the la rge pan, about 7,000 grams (ne a rly 16 pounds). Samples ranged in size from those that filled only one small pan to those that filled seven or eight pans of both sizes and totaled 40,000 to 50,000 grams, or about 100 pounds. The samples were concentrated by panning until most of the light-colored (light weight) mineral grains were washed from the pan. Concentrates consisted mostly of dark-cclored heavy minerals, commonly with some fresh sulfides, mainly pyrite. At each locality where two or mor $:$ pans of sand and gravel were taken, the concentrates from each pan were combined into one sample for anal'sis. Samples of concentrate ranged in weight from a fe grams to as much as 775 grams. Some samples were panned by one person alone; others, by two, three, $c r$ four people.

In the labor a tory, concentrate samples weighing more than about 50 grams were split in a Jones splitter to samples of about 50 grams. Using ceramic plates, these 50-gram splits were then ground to about 80 to 100 mesh. If the original concentrate sample was less than about 50 grams, the entire sample was ground. If the ground sample weighed less than absut 15 grams, the whole sample was analyzed in one run. If the ground sample weighed more than about 15 grams, it was poured into a cone-shaped pile on a flat surface, and 
was spread out rather evenly; enough spatula scoops, each containing about 1 gram of sample, were taken to make two or three separate splits for analysis, usually of about 15 grams each. For each analysis, a gold-silver bead was obtained by the standard fireassay method. This bead was dissolved in acid and the gold was determined quantitatively by atomic-absorption spectrometry (Huffman and others, 1967). The limit of detection is 0.02 part per million (ppm) gold for samples of 10-15 grams and is slightly higher for smaller samples.

\section{SAMPLE DATA AND ANALYTICAL RESULTS}

Tables 1, 2, and 3 show sample data and analytical results. Not much significance is placed on the calculated amount of gold in the field samples beyond its order of magnitude-the weight of the field sample was only estimated; thus the concentration ratio cannot be figured precisely. Furthermore, the amount of gold in the concentrate is minimal, because gold can be lost in panning; however, the amount that might have been lost is not known. On the other hand, considerable significance can be placed on the consistency of the analytical results and their quantitative compatibility with geologic relations.

\section{Consistency of analytical results}

Because gold is particulate in habit, has a high specific gravity, and is malleable, it is commonly difficult to grind and mix a sample sufficiently to obtain consistent analytical results between sample splits. Splits of the pan concentrates used in this study, however, gave reasonably consistent results, as shown both by graphic plotting and by statistical analyses. The consistency between splits permits placing considerable confidence in the determinations for those samples on which only one analysis was made.

The analytical determinations for the samples listed in tables 2 and 3 that were analyzed as two or three separate splits are plotted on a logarithmic scale in figure 1. For most samples, the logarithmic range (length of line) between plotted points is small and is about the same for low-grade and high-grade samples. For a few low-grade samples $(054,114$, and 335$)$, as might be reasonably expected, the logarithmic range appears 1 a $\mathrm{rge}$ although the actual d ifferences are small-indeed, the happenstantial inclusion or exclusion of perhaps a single particle of gold in a sample split might make the difference between splits.

Quantitative compatibility of samples with known geologic relations

The 57 samples used in this study were taken from streams draining three geologic types of groundapparently barren, weakly mineralized, and wellmineralized (fig. 2). The analytical results show a quantitative compatibility between the samples and their source areas.
Table 1 lists samples taken from the Middle and West Forks of Cimarron Creek. These two drainage areas contain no known ore deposits and only a few fractures along which hydrothermal alteration was relatively weak. All 21 samples, which are concentrates from a total of about 600 pounds of sand and gravel, and which were analyzed in 42 splits, were reported to contain less than the limit of detection, usually $<0.02 \mathrm{ppm}$ gold. Calculating these results into the volumes of the field samples gives values not exceeding tenths or hundredths of a part per billion (ppb), or $0.000 \mathrm{X}$ to $0.0000 \mathrm{X}$ ppm, probably one to two orders of magnitude less than crustal abundance.

Table 2 lists samples from streams that drain areas classed as weakly mineralized, in which veins are not abundant and only a few prospects or small mines are known. Table 3 lists samples from streams draining well-mineralized areas that contain numerous veins and some very productive mines. Of the 35 samples shown on these two tables, all were reported to be gold-bearing except one, sample 354 (table 2), which is from a stream draining a weakly mineralized area. The calculated gold content of the sand and gravel from streams draining weakly mineralized areas (table 2) ranges from a few tenths of a ppb to several ppb, or 0.0003 to $0.009 \mathrm{ppm}$. The samples from streems draining well-mineralized areas have calculated gold values ranging from several $\mathrm{ppb}$ to a few hundred $\mathrm{ppb}$, or 0.006 to $0.3 \mathrm{ppm}$. Gold was reported in the analyses of all samples and sample splits, and was observed in the field in the pan concentrates in 13 out of 15 samples that were found on analysis to contain a calculated gold content of at least $0.01 \mathrm{ppm}$. It is wcrth noting that $0.01 \mathrm{ppm}$ of gold is equivalent to about 1 cent per cubic yard of sand and gravel and is below the limit of detection by common analytical methods. Obviously, a fairly consistent field recognition of such low gold values gives useful information on the spot.

\section{CONCLUSIONS}

The consistency of replicate analyses permits placing considerable confidence in the sampling and analytical methods used, and the quantitative compatibility with known geologic relations indicates that a few samples are adequate to distinguish between "barren" and mineralized areas and to determine the relative amount of gold in mineralized areas. In other areas where similar gold deposits might be present, the analytical results of this type of sampling should be useful to determine easily and quickly whether more intensive search for gold deposits might be justified.

\section{REFERENCE CITED}

Huffman, Claude, Jr., Mensik, J. D., and Riley, L. B., 1967, Determination of gold in geologic materials by solvent extraction and atomic-absorption spectrometry: U.S. Geol. Survey Circ. 544, 6 p. 
FIGURES 1, 2 AND TABLES 1-3 


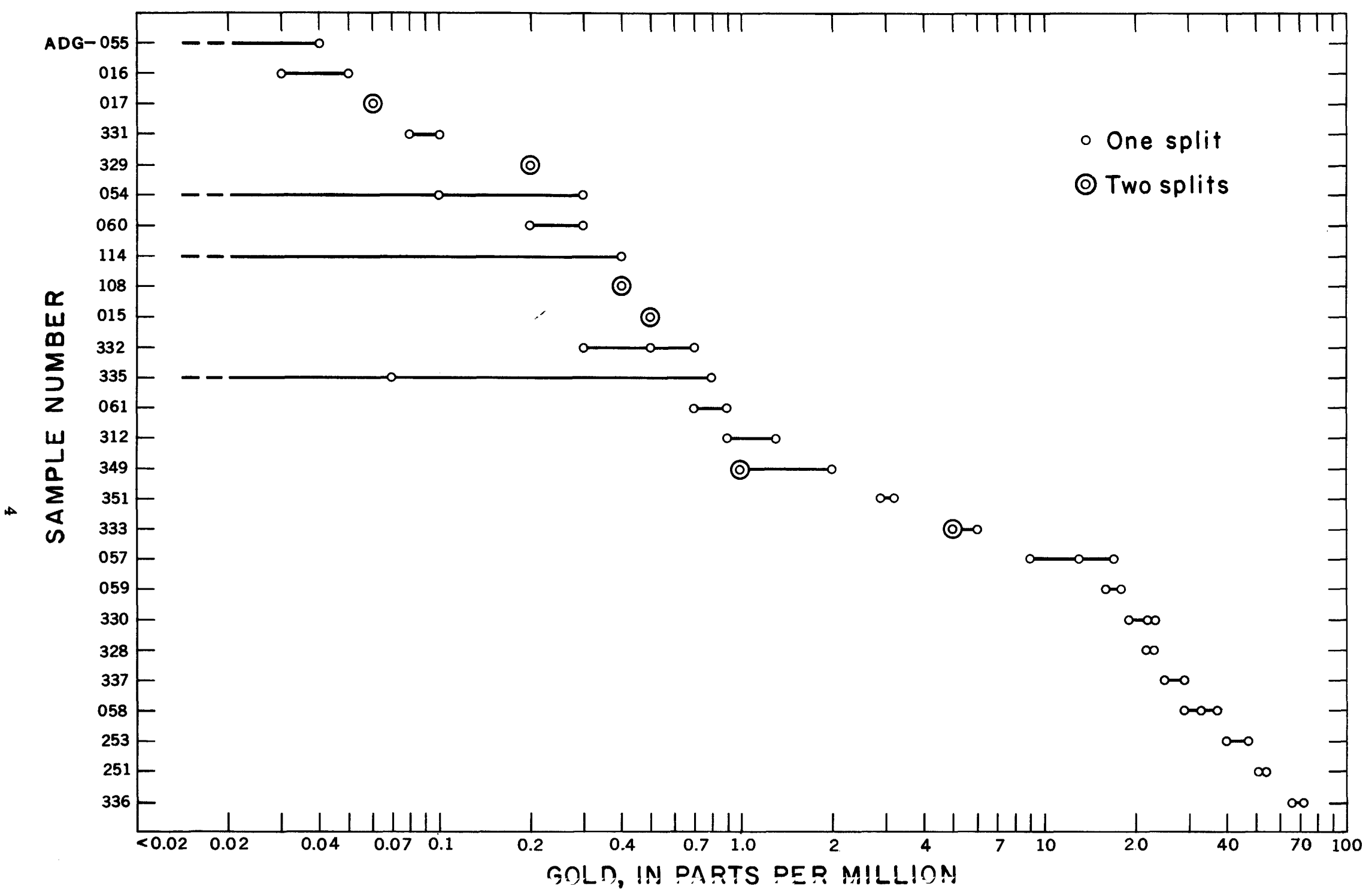

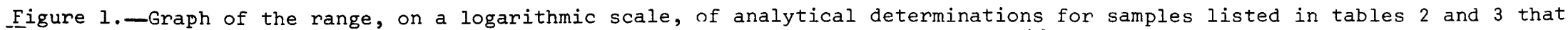
were analyzed as two or three separate splits. 


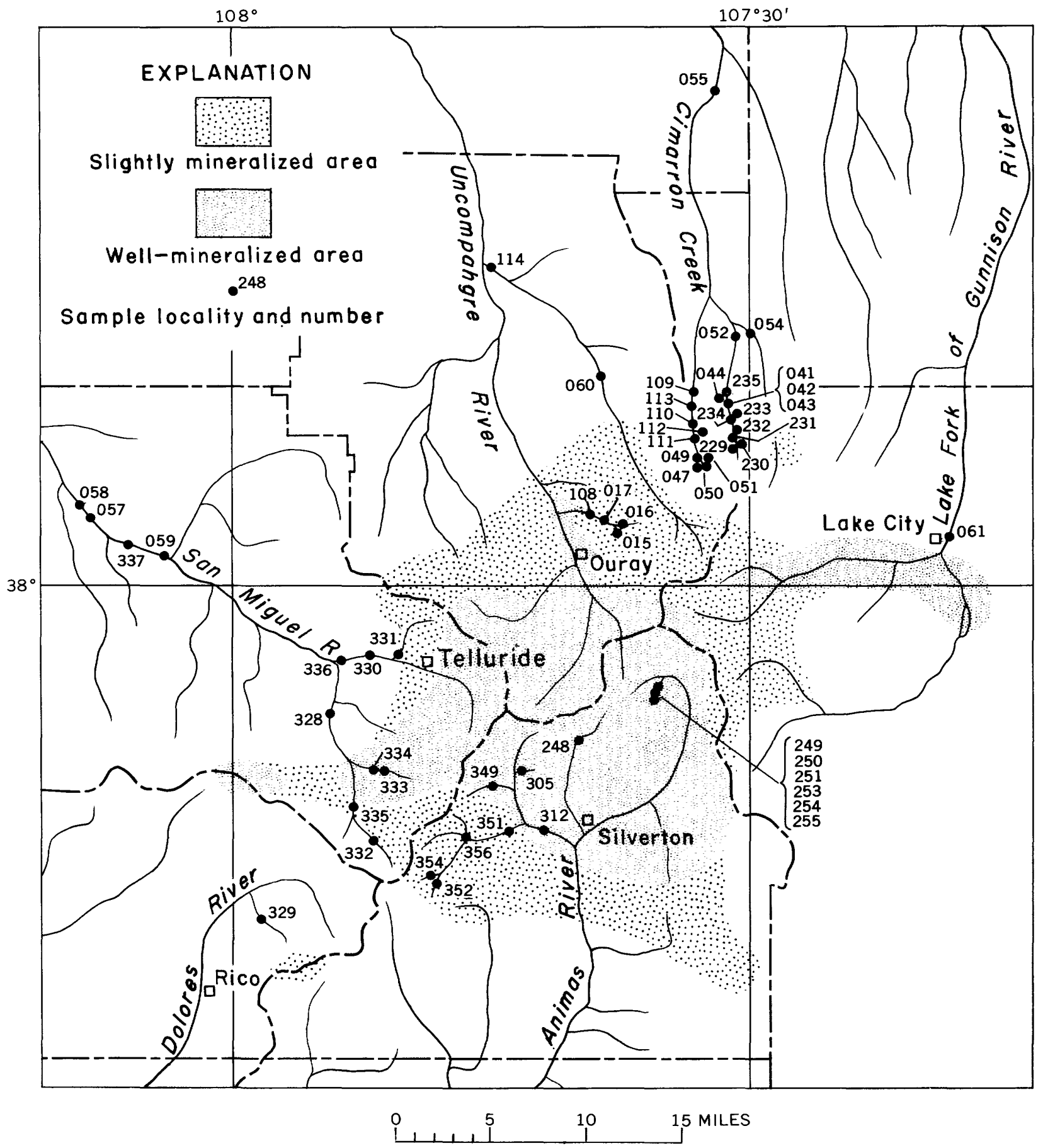

Figure 2.-Map showing sample localities and character of mineralized areas in San Juan Mountains, colo. 
Table 1.--Samples from streams

\begin{tabular}{|c|c|c|c|c|c|}
\hline \multirow{2}{*}{$\begin{array}{l}\text { Sample } \\
\text { No. }\end{array}$} & \multirow{2}{*}{$\frac{\text { Field sample }}{\text { Weigh }}$} & \multirow{2}{*}{$\frac{\text { Concentrate }}{\text { rams }}$} & \multirow{2}{*}{$\begin{array}{l}\text { Concentration } \\
\text { ratio }\end{array}$} & \multicolumn{2}{|c|}{$\begin{array}{c}\text { Concentrate analyzed } \\
\text { (weight in grams) }\end{array}$} \\
\hline & & & & Split 1 & Split 2 \\
\hline \multicolumn{6}{|c|}{ West Fork Cimarron Creek } \\
\hline $\begin{array}{r}\text { ADG - } 047 \\
049 \\
050 \\
051 \\
109 \\
110 \\
111 \\
112 \\
113\end{array}$ & $\begin{array}{r}10,000 \\
7,000 \\
7,000 \\
7,000 \\
40,000 \\
50,000 \\
40,000 \\
3,500 \\
20,000\end{array}$ & $\begin{array}{c}26.77 \\
18.35 \\
36.31 \\
24.27 \\
775.8 \\
89.8 \\
483.1 \\
40.2 \\
219.4\end{array}$ & $\begin{array}{r}380 \\
380 \\
200 \\
280 \\
50 \\
550 \\
80 \\
90 \\
90\end{array}$ & $\begin{array}{l}15 \\
10 \\
15 \\
12 \\
15 \\
15 \\
15 \\
15 \\
15\end{array}$ & $\begin{array}{r}11.77 \\
8.35 \\
21.31 \\
12.27 \\
15 . \\
15 . \\
15 . \\
15 . \\
15 .\end{array}$ \\
\hline \multicolumn{6}{|c|}{ Middle Fork Cimarron Creek } \\
\hline
\end{tabular}

Table 2.-Samples from streams draining weakly mineralized areas

\begin{tabular}{|c|c|c|c|c|c|}
\hline & Sample locality & & & $\begin{array}{c}\text { Concentration } \\
\text { ratio }\end{array}$ & $\begin{array}{l}\begin{array}{c}\text { Concentrate analyzed } \\
\text { (weight in grams) }\end{array} \\
\text { Split } 1 \\
\text { Split } 2\end{array}$ \\
\hline $\begin{array}{r}A D G-055 \\
054\end{array}$ & $\begin{array}{l}\text { Cimarron Creek } \\
\text { East Fort }\end{array}$ & $\begin{array}{l}14,000 \\
17,000\end{array}$ & $\begin{array}{l}266.9 \\
270.1\end{array}$ & $\begin{array}{l}50 \\
60\end{array}$ & $\begin{array}{l}15 \\
15\end{array}$ \\
\hline
\end{tabular}

Uncompahgre River drainage area

\begin{tabular}{|c|c|c|c|c|c|c|}
\hline $\begin{array}{l}060 \\
114 \\
015 \\
016 \\
017 \\
108\end{array}$ & 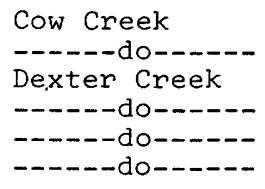 & $\begin{array}{r}14,000 \\
40,000 \\
14,000 \\
7,000 \\
9,000 \\
40,000\end{array}$ & $\begin{array}{l}214.5 \\
460.6 \\
17.22 \\
53.5 \\
59.7 \\
265.3\end{array}$ & $\begin{array}{r}60 \\
90 \\
800 \\
130 \\
150 \\
150\end{array}$ & $\begin{array}{l}15 \\
15 \\
10 \\
15 \\
15 \\
15\end{array}$ & $\begin{array}{l}15 \\
15 \\
7.22 \\
15 \\
15 \\
15\end{array}$ \\
\hline \multicolumn{7}{|c|}{ Animas River drainage area } \\
\hline \multicolumn{7}{|c|}{ San Miguel River drainage area } \\
\hline 329 & Barlow Creek & 20,000 & 43.5 & 460 & 15 & 15 \\
\hline
\end{tabular}

I' Gold was recognized visually in the pan. 
draining apparently barren areas

\begin{tabular}{|c|c|c|c|c|c|c|}
\hline \multirow[b]{3}{*}{$\begin{array}{c}\text { Sample } \\
\text { No. }\end{array}$} & \multirow{3}{*}{$\begin{array}{c}\text { Concentrate } \\
\text { analyzed-Con. } \\
\text { (weight in grams) } \\
\text { Split } 3\end{array}$} & \multicolumn{5}{|c|}{ Gold content in parts per million } \\
\hline & & \multicolumn{4}{|c|}{ Concentrate } & \multirow{2}{*}{$\begin{array}{c}\text { Field } \\
\text { sample } \\
\text { (celculated) } \\
\end{array}$} \\
\hline & & Split 1 & Split 2 & Split 3 & Average & \\
\hline $\begin{array}{r}\text { ADG - } 047 \\
049 \\
050 \\
051 \\
109 \\
110 \\
111 \\
112 \\
113\end{array}$ & $\begin{array}{l}--- \\
--- \\
--- \\
--- \\
--- \\
--- \\
-- \\
--- \\
---\end{array}$ & $\begin{array}{l}<0.02 \\
<.02 \\
<.02 \\
<.02 \\
<.02 \\
<.02 \\
<.02 \\
<.02 \\
<.02\end{array}$ & $\begin{array}{l}<0.02 \\
<.02 \\
<.02 \\
<.02 \\
<.02 \\
<.02 \\
<.02 \\
<.02 \\
<.02\end{array}$ & $\begin{array}{l}--- \\
--- \\
--- \\
--- \\
--- \\
--- \\
--- \\
--- \\
---\end{array}$ & $\begin{array}{l}<0.02 \\
<.02 \\
<.02 \\
<.02 \\
<.02 \\
<.02 \\
<.02 \\
<.02 \\
<.02\end{array}$ & $\begin{array}{l}<0.0000 \mathrm{X} \\
<.0000 \mathrm{X} \\
<.0000 \mathrm{X} \\
<.0000 \mathrm{X} \\
<.000 \mathrm{X} \\
<.0000 \mathrm{X} \\
<.000 \mathrm{X} \\
<.000 \mathrm{X} \\
<.000 \mathrm{X}\end{array}$ \\
\hline \multicolumn{7}{|c|}{ Middle Fork Cimarron Creek } \\
\hline
\end{tabular}

that contain only a few veins and prospects or small mines

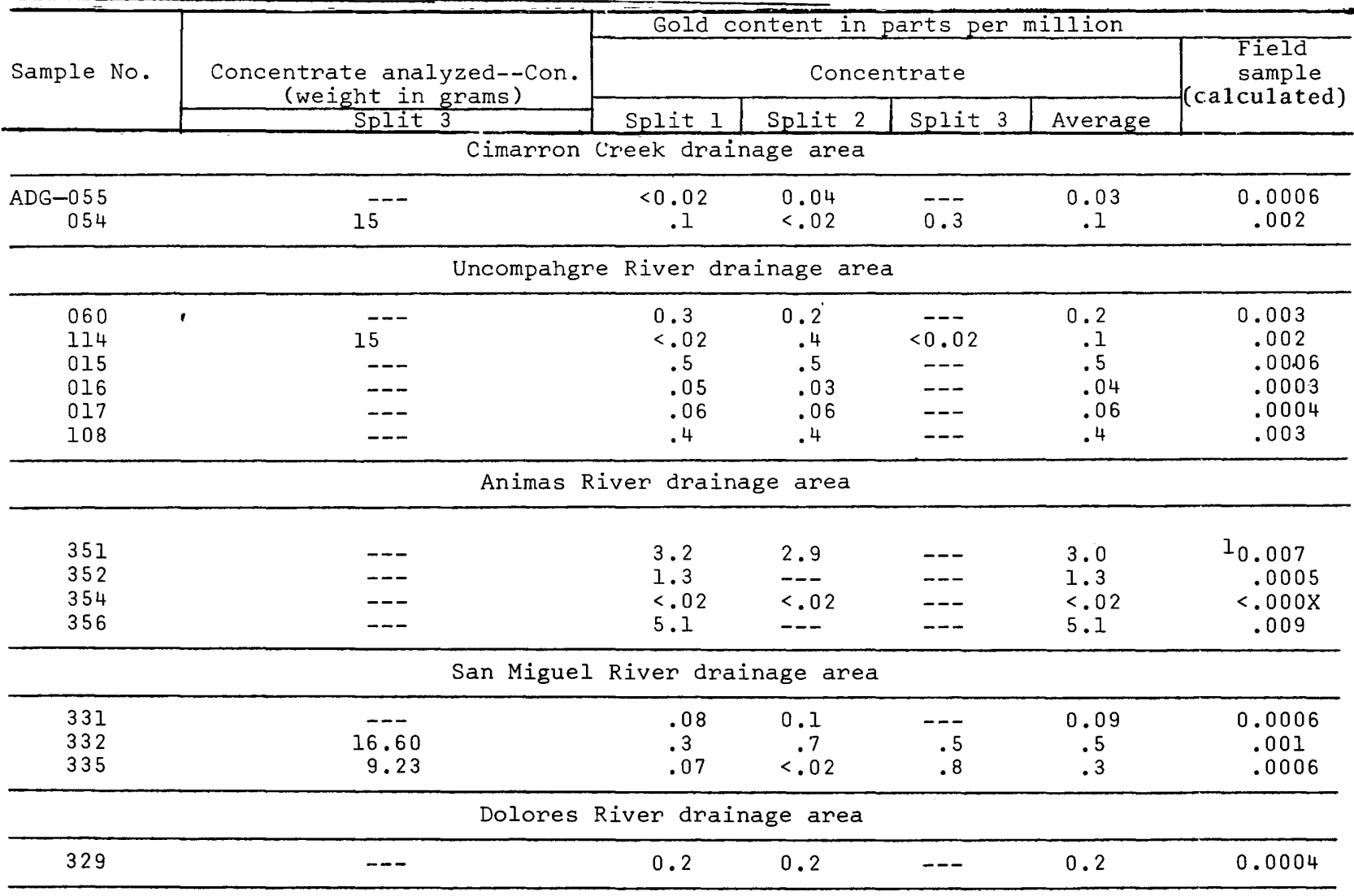


Table 3.--Samples from streams draining well-mineralized areas

\begin{tabular}{|c|c|c|c|c|c|c|}
\hline \multirow{3}{*}{ Sample No. } & \multirow{3}{*}{ Sample locality } & & & \multirow{3}{*}{$\begin{array}{c}\text { Concentration } \\
\text { ratio }\end{array}$} & \multicolumn{2}{|c|}{$\begin{array}{l}\text { Concentrate } \\
\text { analyzed }\end{array}$} \\
\hline & & Field sample & Concentrate & & (weight & in grams) \\
\hline & & Weight & grams & & Split 1 & Split 2 \\
\hline
\end{tabular}

Lake Fork of Gunnison River drainage area

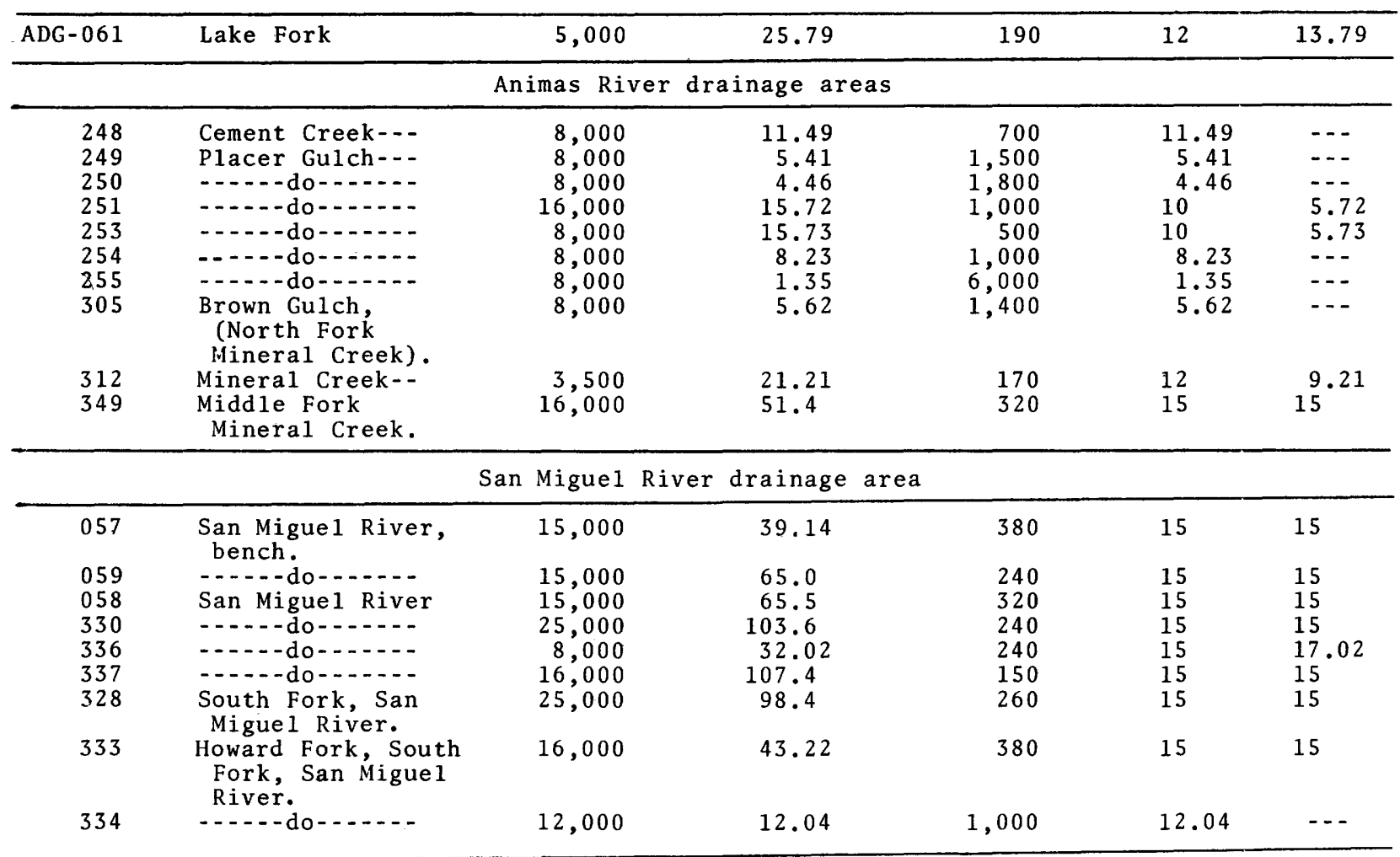

1/Gold was recognized visually in the pan. 


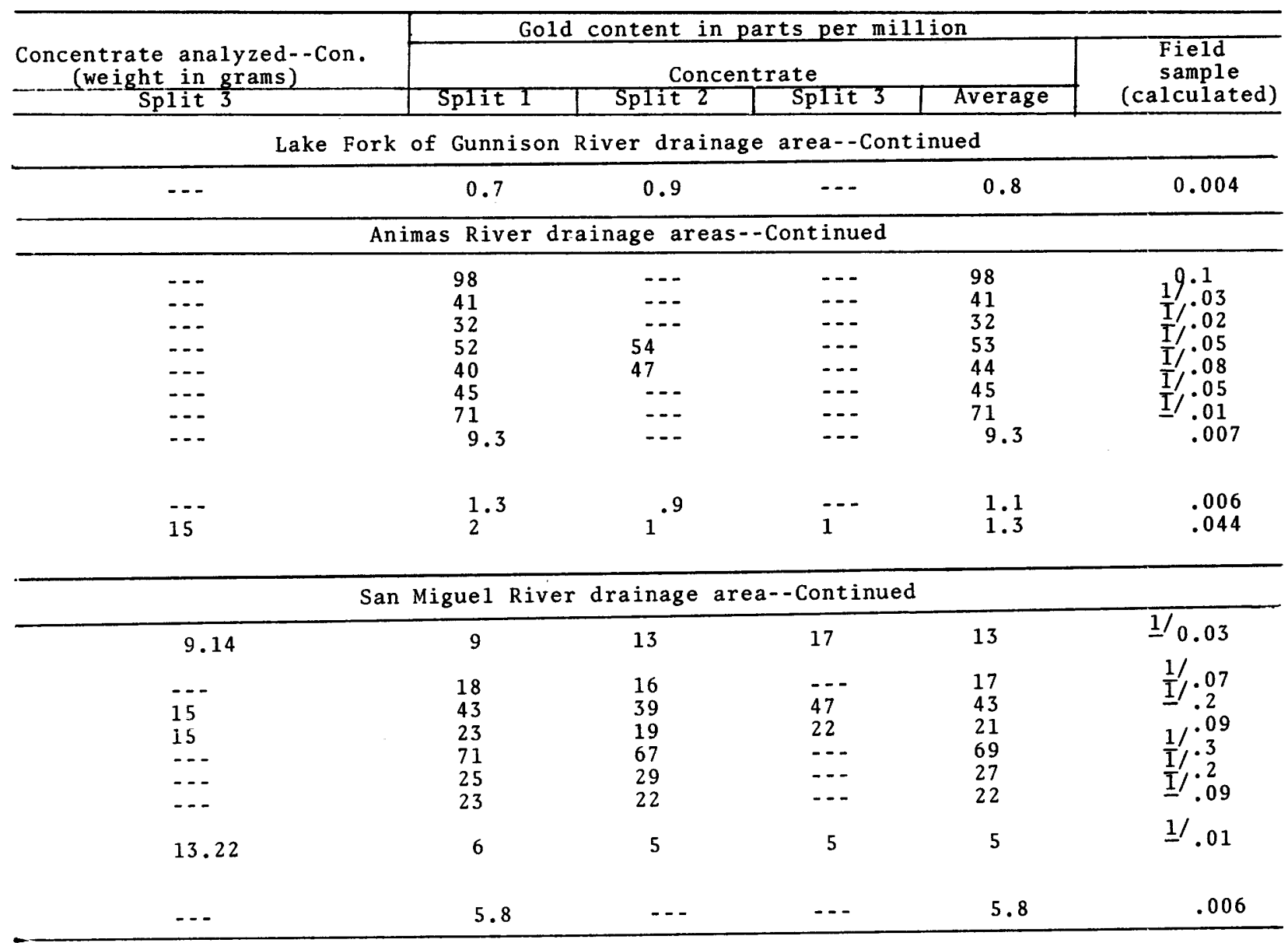




